Radka Vanickova,

Ph.D., Institute of Technology and Business in Ceské Budejovice, Czech Republic

ORCID ID 0000-0003-3559-5799,

email: vanickovaradka@gmail.com

\title{
INNOVATION CORPORATE ENERGY MANAGEMENT: EFFICIENCY OF GREEN INVESTMENT
}

Abstract. The main purpose of the research is to assess the corporate energy efficiency of investment subsidies with or without the possibility of drawing on subsidies or without support from the Operational Program Enterprise and Innovation. Systematisation literary sources and approaches for solving the problem is processed according to the methodology of the Operational Program Enterprise and Innovation, Eco-energy program indicates the comparison with real and expected savings of energy concerning the corporate energy efficiency of investment subsidies provided to maintain the principles of EU environmental policy and rules for subsidies on a general level in the Czech Republic, complemented by graph illustration of time series of development of sales in the horizon of the years 2011-2015. The relevance of the decision of this scientific problem is that the provision of subsidies from European climate protection funds can contribute to energy savings and air quality. Investigation of the topic within a methodical survey is processed by the research of Czech and foreign scientific literature in the paper is carried out in the following logical sequence: is the creation of a graph and tables taking into account investments and implemented measures with the evaluation of investment efficiency. Methodological tools of the research methods were the comparison was made between the Eco-energy and Potential subsidy programs. The object of research is the chosen company in the South Bohemia region in manufacturing in the Czech Republic plant with 480 employees because, namely an annual turnover of CZK 520 million in 2015. The paper presents the results of an empirical analysis of statistical data, documents and databases of state and private institutions, particularly Ministry of Industry and Trade, Ministry for Regional Development and the Czech Invest Agency. The research empirically confirms and theoretically proves that the net present value, which expresses the total present value of the cash flows related to the investment project, the simple and the real-time of return on investments and the internal rate of return is significant to efficiency. The results of the research can be useful to reduce greenhouse gas emissions, save electricity and thermal energy. The research empirically confirms and theoretically proves that the net present value, which expresses the total present value of the cash flows related to the investment project, the simple and the real-time of return on investments and the internal rate of return is essential for efficiency.

Keywords: EU environmental policy, structural funds, operational program enterprise and innovation, corporate energy efficiency, investment subsidies, net present value.

Introduction. The presented contribution points to the evaluation of the effectiveness of investment subsidy titles with or without the possibility of drawing subsidies from the Operational Program Entrepreneurship and Innovation, say (Moen, 2019; Sobotkova, 2015), which replaces the Operational Program Industry and Enterprise, which was declared for the programming period 2000-2006, respectively 2004-2006 (shortened period due to entrance of the Czech Republic into the EU in 1st May 2004). Operational Program Entrepreneurship and Innovation was prepared for the period 2007-2013 by the Ministry of Industry and Trade of the Czech Republic, in which 15 support programs were, announced (Radicic \& Pugh, 2017). The latest announced Operational Program Entrepreneurship and Innovation for Competitiveness in the period 2014-2020 to increase competitiveness in industry, services and entrepreneurship, innovation support and to sustaining the attractiveness of the Czech Republic for foreign investors (Klímova \& Zitek, 2015; Sedlacek, 2015) for these purposes were allocated funds into so-called priority axes and specific objectives (Agovino, Casaccia, \& Crociata et al., 2019).

Cite as: Vanickova, R. (2020). Innovation Corporate Energy Management: Efficiency of Green Investment. Marketing and Management of Innovations, 2, 56-67. http://doi.org/10.21272/mmi.2020.2-04 
The Potential program aimed to support increasing or a new capacity introduction in the company that will lead to the realisation of development (Dyba, Loewen, Looga et al., 2018) research and innovation activities together with the expected increase in the number of enterprises that will be able to carry out their research, development and innovation in order to deepen cooperation with research organisations (Chabbi, Loescher, \& Dillon, 2017) by creating new qualified jobs, the improvement of conditions (improving the conditions) for the integration of enterprises into national and European programs of research and development with the support of increasing the competitiveness of the Czech economy. The Eco-Energy Program implemented Priority axis 3 «Efficient Energy» of the OP Entrepreneurship and Innovation 2007-2013 under Act No. 47/2002 Coll. on the support of small and medium-sized enterprises (Liu \& Xie, 2013) as subsequently amended, Commission Regulation (ES) No. 1998/2006 of 15th December 2006 on the application of Articles 87 and 88 of the Treaty about the European Community (ES) within support of de Minimis under Commission Regulation (ES) No. 1628/2006 of 24th October 2006 on the application of Articles 87 and 88 of the Treaty about the European Community concerning internal regional aid.

The administrator of the program was the Ministry of Industry and Trade of the Czech Republic, whose state-funded institution called Agency for support of entrepreneurship and investment Czech Invest was mediate body, Bohemian-Moravian guarantee and development bank was the support provider of the subordinated loan with a financial contribution (Klímova \& Zitek, 2015). The objective of the Eco-energy program was to subsidise small and medium-sized enterprises with subsidy support or in the way of subordinated loans with a financial contribution in order to reduce the energy demand of production (Levanen \& Eloneva, 2017; Miller \& Senadeera, 2017) consumption of primary energy resources (Andersen, Baldini, Hansen et al., 2017) and higher use of renewable resources. Support was provided to reduce the energy demand per unit of production while keeping the long-term stability and availability of energy for the business sphere, reducing the dependence of the Czech economy on imports of energy commodities, reducing the consumption of fossil primary energy resources, supporting the growth of renewable energy resources, exploit the potential of energy savings and renewable energy resources and for large companies to evaluate the secondary use of energy resources.

Literature Review. With the increasing growth of human population according to (Arbolino, Romano, \& De Simone, 2017) rising GDP levels and more affluent lifestyles, the human race is consuming more and more which leads to a continuously growing demand for renewable and nonrenewable resources. Therefore, the issue of resource scarcity is emerging because it is questionable whether economic growth can be sustained in a world with finite natural resources. The most important approach is the development of new technologies that economise on scarce resources or allow us to use resources that were previously uneconomical. These technologies enable us to realise the productivity growth that we need to satisfy the ever-growing consumption, while not increasing the demand for resources significantly. The production processes within Industry 4.0 should be seen as holistic, balanced circuits, which guide and shape the new industrial production (Junker \& Domann, 2017; Miller \& Carriveau, 2018). Technologies which also emerge within the new age of manufacturing (Knoke, Missikoff, \& Thoben, 2017; Latif, Gopalakrishnan, Nimbarte et al., 2017), can be used to trace materials through the supply chain, fractions and to track product status. To overcome the severe environmental, economic and social problems the present time and tomorrow, system thinking skills, in conjunction with a comprehensive, integrated understanding of technology and data will be essential. These advances in technology will be created ever more excellent opportunities to accelerate the transition towards the model of a circular economy (Mahmood, Javaid, Ahmed et al., 2017). Smart products and Industry 4.0 technologies can generate significant economic, environmental and social benefits (Adamisin, Kotulic, Mura et al., 2018) and they could contribute towards a circular economy, 
which could be the solution to harmonise ambitions for economic growth and environmental protection (Burrascano, Chytry, Kuemmerle et al., 2016).

When the Czech Republic entered to European Union in 2004 created the space has brought new business opportunities to Czech entrepreneurs (Scheurer \& Haase, 2018), a more competitive market environment with the possibility of allocating business activities between individual Member States of the EU. Due to the existence of economic and social disparities between individual states, comments (Indradewa, Tjakraatmadja, \& Dhewanto, 2017) in the EU has established a regional policy aimed at reducing the differentiation between individual regions of the EU Member States at international, national, regional and local levels in order to promote and harmonise the level of partial regions which underdeveloped behind the European average (Felixova, 2012; Havlík, 2018).

The EU regional policy focuses on the promotion of solidarity and cohesion in individual Member (Dziembala, 2016; Percoco, 2017), with the possibility of drawing financial support from the Structural Funds providing funding from the Operational Programs, how to say (Alons, 2017; Kisiala, Bajerski, \& Stępinski, 2018; Tascu, 2014). The EU is also engaged in the field of renewable energy resources in order to increase its energy efficiency (Carley, Baldwin, MacLean et al., 2017; Trianni, Cagno, \& De Donatis, 2014). The direct impact of the energy policy of the $\mathrm{EU}$ results in a global reduction of $\mathrm{CO}_{2}$ emissions which cause greenhouse effect (Annadanam \& Kota, 2019; Ishikawa \& Okubo, 2017; Lim, Kim, Cho et al., 2017; Waldo \& Paulrud, 2017), but also the global warming of the planet (Al-Masri, Abu Elrub, Almehizia et al., 2019). Stopping the increase in $\mathrm{CO}_{2}$ production by adopting a new measure, the $\mathrm{EU}$ intend legislatively reach by reducing the $\mathrm{CO}_{2}$ concentration in the air (Arbolino, Carlucci, Cira et al., 2017).

Methodology and research methods. In the framework of the methodological survey was searched Czech and foreign literature, analysis of statistical data, documents and database of state and private institutions, in particular Ministry of Industry and Trade CZ, Ministry of Regional Development CZ and Agency Czech Invest. Besides, there were analysed the results of partial research projects. Statistical surveys, including analysis of data and outputs, which are the subject of own research focused on the pre-investment phase of project preparation - e.g. detailed identification of business opportunities, preliminary selection, preparation of projects and evaluation of future projects, the composition of the logical framework including the objective and intent of the project, the investor's expectations, including the measure proposal of the introduction of an energy auditing with the support of the EU environmental policy to reduce electric power consumption in the implementation of the investment plan in ISBAN management system for an area of business, logistics, project management, finance and controlling, personnel records and called ENERGOMAT (archiving of energy flows). Methods of documents analysis were drawn from the internal sources of the examined company, e.g. the EA file of selected objects of the production complex, supplement of the EA files of the selected objects, the information journals, and the feasibility study called PES. The qualitative observation method was used to assess the drawing of financial resources from the Structural Funds from the research and development area concerning the acquisition of long term tangible assets.

Workshops and interviews were conducted to determine the internal operation of individual departments of the manufacturing plant dealing with energy policy measures and investment activities. To assess the effectiveness of the investments were used the dynamic methods, e.g. the net present value, which expresses the total present value of the cash flows related to the investment project, the real-time and straightforward of return on investments and the internal rate of return. The comparison was made between the Eco-energy, and Potential subsidy programs have evaluated in the South Bohemia region in manufacturing plant with 480 employees with an annual turnover of CZK 520 million in the Czech Republic in 2015. 
H1: The prerequisite within the PES project in production facilities is to achieve from 10 to $30 \%$ energy savings concerning the overall reduction of emissions.

$\mathrm{H}$ 2: The possibility of obtaining a subsidy from the Structural Funds with the effectiveness of an investment project will be far more beneficial.

$\mathrm{H} 3$ : Investments in the expansion and modernisation of production space will be very beneficial for the economic and environmental effect.

Results. For the purpose of characterising the investment activity of the manufacturing company, annual reports and final accounts from 2011 to 2015 were used as the basis for creating a graphical representation of summary of the total revenue compared to the long-term tangible assets, including received subsidies to support technical development and research of which provider was the Ministry of Industry and Trade of the Czech Republic, which provided in 2004 the subsidy for acquisition of long term tangible assets (acquisition of technology used for cast iron pump (further just «TELIC») in the amount of CZK 7.074 000. In a project called Project of Energy Savings (further just «PES»), was provided with a subsidy of CZK 1.709000 in 2014, CZK 5.463000 in 2015.

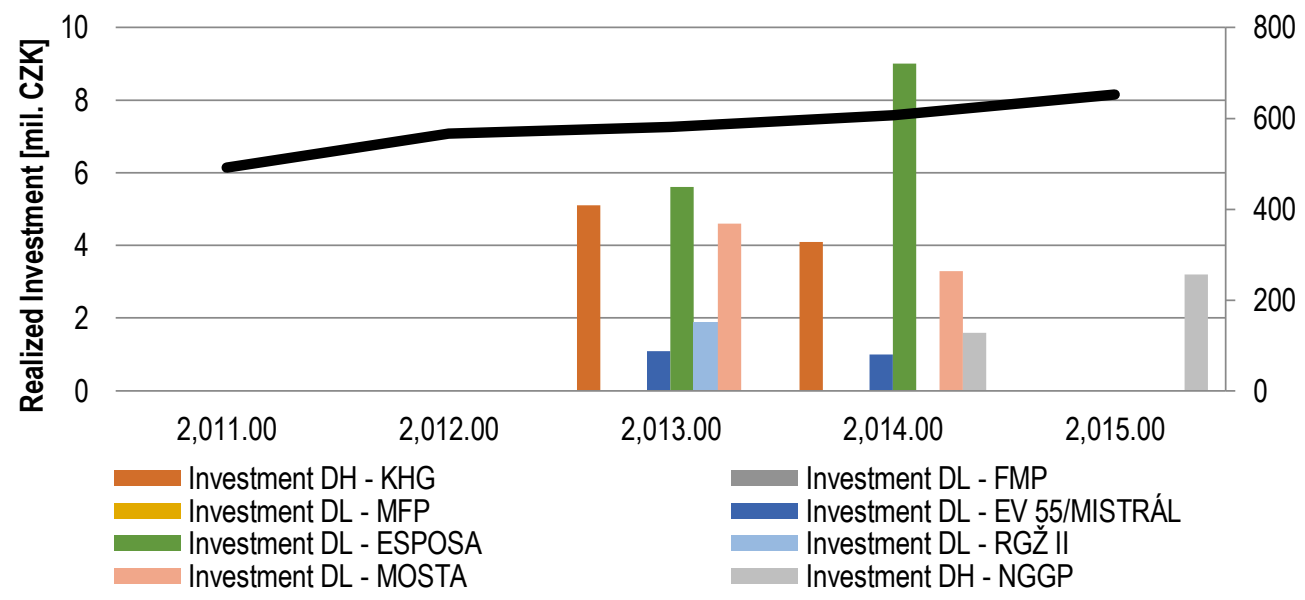

Figure 1. Development of total sales compared to long-term intangible assets

Source: developed by the authors.

Figure 1 shows the progress of total sales (CZK 2.98,2 million) between 2011 and 2015 compared to the course of the invested investments into long-term intangible assets, which amounted to 18.300000 CZK in 2013, of which 5.100000 CZK at the division of hydraulics (KHG), in the division of aviation (FMP) and the MFP were zero, in EV 55/MISTRAL 1.100000 CZK, ESPOSA 5., 600000 CZK, RGZ II $1.900000 \mathrm{CZK}$ and MOSTA $4.600000 \mathrm{CZK}$. The amount of finance into long term intangible assets was allocated to activation of expenditure on research, developmental and developing projects.

Comparison of Eco-energy and Potential programs. The Ministry of Industry and Trade of the Czech Republic announced in the framework of the OP of Entrepreneurship and Innovation for competitiveness for the programming period 2014-2020 support program Energy savings and Potential (Felixova, 2012; Lenkova, Kot, Yakunina et al., 2018). The PES project from the Energy saving program and the TELIC project from the Potential program was elaborated in the programming period 2007-2013 under the Enterprise and Innovation program (Kostic, 2016). Since because these programs are different, they cannot be analysed or evaluated, the Energy savings program has been included in Priority axis 3 , which focuses on the area of energy infrastructure and renewable energy resources in terms of efficient 
use of energy and support in using new technologies in energy and secondary raw materials (Carley, Baldwin, MacLean et al., 2017; Trotta, Spangenberg, \& Lorek, 2018).

Priority axis 1 is set for the potential support program and specialises in the development of entrepreneurship and the competitiveness of small and medium-sized enterprises (Bergman, Hutchison, \& Jensen, 2016; Prashar, 2017). The differentness between the two programs is in the thematic focus where the Potential support program falls under thematic objective 1 under Article 9 point 1 of Regulation 1303/2013, which deals with support for research, technological development and innovation, according to (Wokoun, Kolarík, \& Kolaríkova, 2016). Another variety of programs is the target specification (Stefanek \& Bockova, 2011). The Energy saving program aims according to goal specification 3. 2 to increase the energy efficiency of the business sector and the support program Potential according to objective specification 1. 1 point to increasing the innovation performance of businesses.

The difference between the two programs is in the investment priority. According to Article 5 point 4b, Regulation No. 1301/2013, e.g. Regulation of the European Parliament and of the Council (EU) No. $1301 / 2013$ of 17th December 2013 on the European Regional Development Fund, on specific provisions relating to the objective of investment for growth and employment and repealing regulation (EC) No. $1080 / 2006$ is a program of Energy savings included in investment priority $4 b$, which deals with the promotion of energy efficiency and the exploitation of energy from renewable resources. Support program Potential which is according to Article 5 point $1 \mathrm{~b}$, Regulation No. 1301/2013 is included in investment priority $1 \mathrm{~b}$, which has a broader application, e.g. in the form of investment in research and innovation, creation of synergies between enterprises and the academic environment of university schools in the context of theoretical and practical learning and education, transfer to new technologies, ecological innovations (Wilkesmann \& Wilkesmann, 2018) research and development of new products and services (Kulyk \& Skodova Parmova, 2017).

In the framework of the pilot, the survey was financial support from the Potential program was used to develop a research, development and innovation centre for the purchase of new land, buildings and production and technical facilities. From the program of Energy-saving program has subsidised the distribution of electricity (Wolisz, Schutz, \& Blanke, 2017) heat and gas say (Baltensperger, Fuchslin, Krutli et al., 2017) for real estate in order to increase thermal and electrical efficiency (Raji, Srivastava, Singh et al., 2016) the introduction of measurement and control systems, the reconstruction of the lighting of buildings and industrial sites, other measures reducing the energy intensity of buildings by thermal insulation of the perimeter envelope, exchange of door openings, installation of air-conditioning with waste heat recovery (Mageshwaran, Britto, Sivaji et al., 2018; Rogge, De Jaeger, \& Lavigne, 2017) utilisation of waste energy in production processes, increase of energy efficiency of production and technological processes, installation of renewable energy resources and cogeneration units for own consumption.

The TELIC project, which focused on the development of innovative technology, funds from the Ecoenergy program were drawn, compared with the results of the economic management of the production company and the energy savings in the production facilities (Enshassi, Ayash, \& Mohamed, 2018). The project aimed to increase the technical and utility values of the products and to streamline the production processes of the company. The project involved the purchase of new production technology for introduction to the production of new and innovative products. The subject of the project was to build on the long-term strategic concept of the production company and the involvement of the production company in the national and European programs of research and development and the continuous improvement of the competitiveness of the Czech economy. The project of savings energy (PES) on the premises of the manufacturing company was positioned for austerity measures in energy consumption in the division of the hydraulics and aviation production. 
The objective of the PES project (feasibility study) was to improve the thermal and technical properties of buildings intended for production purposes, e.g. through the replacement of windows, thermal insulation of buildings, modernisation or reconstruction of heating systems (Mense, 2018) reduction of losses in heat distribution in production halls, including the introduction of high-efficiency (Sineviciene, Sotnyk, \& Kubatko, 2017) combined electricity and heat production for own consumption of the production company. Another essential objective of the project was to reduce the energy intensity of the main production processes at the production buildings with the emphasis on the reduction of the value of consumption in electric power in the way of modernisation of the production hall lighting system. The PES project was designed in line with the EU's strategic goals to reduce greenhouse gas emissions by 2020 by $20 \%$ (Spiller, Sopher, Martin et al., 2017). Within the PES project, at least $30 \%$ of energy savings have been achieved in the production facilities that have been integrated into the project in order to achieve a reduction of emission of $\mathrm{CO}^{2}$ in value of 1.917 t/year in comparable manufacturing activity over the last three years including reducing the company's energy costs to a numerical value of $6.684,4$ $000 \mathrm{CZK}$ for the last three-year period. For the calculation of the carbon dioxide emission factor were used values from Regulation 480/2012 Coll. on energy audit and energy assessment (Monasterolo \& Raberto, 2019; Vochozka \& MarouSkova, 2017). According to the results of the energy audit, the total energy savings of $7.665 \mathrm{GJ} /$ year (the difference before project implementation was $40.141,0 \mathrm{GJ}$ after the realisation of the project was estimated at $3.2476,0 \mathrm{GJ}$ ) was confirmed. In the area of environmental benefits relative to pollutant $\mathrm{CO}^{2}$, whose initial state was estimated at 5.822 tyear, the state after implementation decreased to 3.905 t/year, where the total $\mathrm{CO}^{2}$ savings amounted to $1.917 \mathrm{t} / \mathrm{year}$ (the actual saving was in the year 2014 compared to 2012 for electric power of $503 \mathrm{MWh}$ and 6.150,7 MWh for natural gas).

To evaluate the effectiveness of investment projects was used feasibility study, funded by the funds of the Eco-energy grant program, in which was provided with the applicant's identification data, project description and technical specification of the project, project timetable and financial analysis of the project. In the framework of the investment preparation of the project was assigned to the external processor, Energy Consulting Service Company to prepare an energy audit for the objective assessment of the proposed energy savings. In order to fulfil the objective of the contribution, the effectiveness of the project with financial participation from the Eco-energy subsidy program (extended III. call within the Operational Program Enterprise and Innovation) was analysed. Duration of write-off period was set at 30 years due to the real depreciation period. Based on the obtained results, it was found that the subsidy variant of the participation of the funds from the Structural Funds is more cost-effective than the option without drawing a financial subsidy - see Tab. 1. Comparison of real and expected corporate energy efficiency of investments subsidies was related to the 30th year period. In Tab. 2, 3 and 4, show the comparisons of the energy effectiveness of the investments supported from the funds drawn from the Structural Funds, but without subsidies to the individual production facilities.

Table 1. Production facility M02

\begin{tabular}{ccccc}
\hline Investment & $\begin{array}{c}\text { CSH } \\
\text { (thousand CZK) }\end{array}$ & Ts (year) & Tsd (year) & IRR (\%) \\
\hline Planned with a subsidy & -4161 & 33 & $>30$ & - \\
Planned without a subsidy & -5601 & 47 & $>30$ & - \\
Real with subsidies & -4056 & 32 & $>30$ & - \\
Real without subsidies & -5469 & 46 & $>30$ & - \\
\hline
\end{tabular}

Note: CSH (Net present value), Ts (single return time), Tsd (Real return time), IRR (Internal rate of return).

Source: developed by the authors. 
According to the facts mentioned above, the realisation of the measures in production facility M02 was not economically favourable even though the management unanimously approved it of the production company. Because of the expected repairs in the M02 building including the planned expansion of the production space and the improvement of the design production company, it is not possible to evaluate objectively the economic contribution of the investment.

Table 2. Production facility M03

\begin{tabular}{ccccc}
\hline Investment & $\begin{array}{c}\text { CSH } \\
\text { (thousand CZK) }\end{array}$ & $\begin{array}{c}\text { Ts } \\
\text { (year) }\end{array}$ & $\begin{array}{c}\text { Tsd } \\
\text { (year) }\end{array}$ & IRR (\%) \\
\hline Planned with a subsidy & 6501 & 6 & 8 & 8,89 \\
Planned without a subsidy & 1611 & 497 & 12 & 5,32 \\
Real with subsidies & 15005 & 323 & 4 & 20,73 \\
Real without subsidies & 12312 & 465 & 6 & 14,29 \\
\hline
\end{tabular}

Source: developed by the authors.

The implemented measures in the case of production facility M03 were economically favourable. Through the methods for evaluating the effectiveness of investments, it has been found out investments to 30 years, and the internal rate of return (IRR) is higher than $4,5 \%$.

Table 3. Production facility M06

\begin{tabular}{ccccc}
\hline Investment & $\begin{array}{c}\text { CSH } \\
\text { (thousand CZK) }\end{array}$ & Ts (year) & Tsd (year) & IRR (\%) \\
\hline Planned with a subsidy & 3645 & 4 & 4 & 19,65 \\
Planned without a subsidy & 2925 & 5 & 6 & 13,5 \\
Real with subsidies & 489 & 8 & 10 & 5,8 \\
Real without subsidies & -1046 & 11 & 16 & 2,81 \\
\hline
\end{tabular}

Source: developed by the authors.

The production company decided to support the variant without a subsidy at production facility M06. However, to higher actual inputs than planned, the difference generated a loss of $1.046000 \mathrm{CZK} / 30$ years. With the allocation of subsidies, the investment income was $489000 \mathrm{CZK}$, the return on investment was confirmed. The increase in real investment costs over the planned was due to the need to meet the conditions of the energy audit, which emphasise energy saving.

Table 4. PES Project

\begin{tabular}{ccccc}
\hline Investment & $\begin{array}{c}\text { CSH } \\
\text { (thousand CZK) }\end{array}$ & Ts (year) & $\begin{array}{c}\text { Tsd } \\
\text { (year) }\end{array}$ & IRR (\%) \\
\hline Planned with a subsidy & 6059 & 7 & 9 & 7,42 \\
Planned without a subsidy & -991 & 10 & 14 & 4,14 \\
Real with subsidies & 11514 & 5 & 7 & 11,01 \\
Real without subsidies & 5873 & 8 & 10 & 7 \\
\hline
\end{tabular}

Source: developed by the authors.

Based on the methods of evaluating the effectiveness of the investments, see Tab. 4, it is clear that the simple and real return on investment method is misleading and inadequate. The return on investment planned without the subsidy of the PES project using the criterion of the simple return on investment has been quantified over 10 years using the criterion of the real return period of the 14 years, which may lead to the limiting conclusion that after 30 years the PES project will be profitable. Using the planned financial means without subsidies is realisation of the PES project after 30 years of operation 
loss-making of CZK 991 000. It is more advantageous and more objective to use the net present value or internal rate of return criterion, see Tab. 4 where the PES project is economically inefficient without subsidies, i.e. even after 30 years of operating activity will not be profitable. Obtaining subsidies decided to start the implementation of the PES project.

Conclusions. The paper aimed to compare the real and expected energy savings and corporate energy efficiency of investment in subsidies under the OP Enterprise and Innovation, the Eco-energy program to reduce and efficiency improvement of energy consumption in the two major production divisions of the joint-stock company, e.g. the hydraulics division and the aviation production division. In the case of the submitted contribution, the priority axis called efficient energy was announced in the Operational Program Enterprise and Innovation. Subsidies amounting to $30 \%$ of the eligible costs for the beneficiary, i.e. large enterprises, could only obtain well-designed projects. Three calls for submitting project applications from the area of renewable energy and energy savings have been announced under the Eco-energy program. In deciding on how to finance investments, the following aspects have been considered, e.g. tax savings (depreciation, interest and lease tax, the advantage of investment in acquisition); interest rates on long-term loans and the repayment schedule; tax depreciation rates and the method of depreciation of long-term assets during their lifetime period; leasing instalments, the amount and duration of the lease term; the factor of time expressed by the chosen discount rate for the cash flow conversion according to the different financing methods and the requirements for the subsidy resources.

The author analysed the effectiveness of the investment plan to find the subsidy support or without support from the Eco-energy program in the comparison of the two alternatives. The methods that were used to evaluate the effectiveness of investments are the net present value method, the real and straightforward return period and the internal rate of return. The above methods have shown that with the support from the Structural Funds, the investment is more efficient. Despite all administrative and technical and other project-intensive activities, it was confirmed that obtaining a subsidy from the Structural Funds is more useful for the entrepreneurial subject than financing the project without subsidies, in order to reduce the investment intensity of the project and its risk. The implementation of the PES project, which started in 2013 and was completed in 2015 by realisation of PES II project which followed after the PES project, decentralisation of the heating production company was completed. In the case of the PES (Project of energy savings), the implementation of the project would not have taken place without the grant of the subsidy in its entirety, as assumed by the energy audit, i.e. it would not achieve the expected savings of a financial or environmental nature.

The PES project would only be implemented in part by a measure in the main production facility, says (Humphreys, 2018). Based on the facts, it can be stated that the acquisition of the subsidy was a decisive criterion that convinced the business entity to take the new measures to obtain from the energy audit. Through support under the subsidy, titles have promoted the development of entrepreneurship and entrepreneurial activities allocating better financial results influenced by energy saving, support of economic stability and economically favourable overall results of management of the production company. Even though there have been significant energy savings, the author of the paper suggests paying more attention to the project's pre-investment phase for other possible follow-up projects, followed by identification of business opportunities, pre-selection and preparation of the project, including the selection of suitable alternatives, evaluation of future projects and decision on their implementation or refusal.

It is essential to put in place a so-called «logical framework» in the pre-investment phase of the project that identifies and analyses problems, sets goals, intentions and expectations of the solution from suitability, adequacy of the problem, feasibility and sustainability of the project based on logical framework methodology. Another recommendation of the author of the paper is to implement measures 
in follow-up energy audits, e.g. to solve the lighting in other buildings and surface insulation of roofs in order to reduce the consumption of electricity and a higher environmental effect in the Czech Republic, respectively the $\mathrm{EU}$ in the sense of respecting the principles of environmental policy EU to protection environment. European trends confirm that the fuel mix in electricity-power engineering will be based on nuclear power with a focus on renewable resources. As part of the development projects, emphasis will be placed on the completion of the Temelín nuclear power plant in the Czech Republic, the completion of the coal portfolio project, but also the construction of the steam-gas power plant in Pocerady in the Czech Republic.

New trends point to an interest in implementing Smart Regional pilot projects, but also to the innovation of block of flats complex from insulation, solar panels, point of view (Stefaniak, 2013) photovoltaic, and batteries to the introduction of natural gas cogeneration units into public buildings and manufacturing plants. They were equipping entire factory halls with smart energy measurement technology for facility engineering show how transparency of energy demand and energy consumption at the individual machine level can be successfully achieved through technology. The long-term prediction implies an increase in demand for electricity due to automation, robotic automation and mechanisation in the manufacturing and technological processes due to Industry 4.0, higher use of household electric appliances, as well as replacement of fossil resources by renewable resources, where energy transfer is often transmitted through electricity.

Emission factors for energy supplied in fuel for other energy carriers other than electricity are globally identical for the whole of Europe. For example, the complete burning of brown coal, i.e. without including the energy conversion efficiency, produces almost the same amount of $\mathrm{CO}^{2}$ in the Czech Republic as in Poland or Germany, similar to natural gas, biomass, heating oil. The benefits of energy savings from nuclear power plants can bring external costs of nuclear power generation of about 0.21 Eurocent/kWh.20 Reduction of the nuclear share electricity generation by $10 \%$ (about 8 TWh) can lead to the benefits of avoiding external costs of around $€ 20$ million per year. Lower greenhouse gas emissions are associated with lower emissions classical pollutants from electricity and heat generation and related externalities. Only in the case of the replacement of the kernel by other sources will there be a slower reduction of externalities than when new nuclear power sources are being built. By replacing fossil fuels in alternative transport, a significant reduction in overall externalities can also be expected from the reduction in greenhouse gas emissions.

The costs associated with the achievement of the Emissions Target will only be significant after 2030. Assuming significant energy savings and the development of hydrogen production technology using solar energy on an industrial scale, it is possible to achieve an $80 \%$ reduction in greenhouse gas emissions in 2050 compared to 1990 without comparable construction costs new nuclear sources. According to the author, the visions for the future is purchasing, and consumptions look at the opportunities for Industry 4.0 in terms of buying energy directly from the producer which may be local energy or a regional wind farm operator. The results of paper obtained point to the fact that saved funding from the Structural Funds can be the development capital of other support and innovation projects responding to technological changes in production concerning the environment and human health, waste of resources, more efficient use of alternative energy sources on a regional level according to the requirements of operators of production units and consumer habits. Implementation of individual projects co-financed by EU funds is one of the possible alternatives to the optimal use of positive externalities. Comparison of Eco-energy and Potential programs in chapter 3 is proof of the realisation of a profitable project co-financed by EU funds with the real-time of return on investment. Providing subsidies from European funds for climate protection contributes to improving air quality and urban transport situations, saving energy, promoting a healthy lifestyle for the population or increasing employment. 


\section{R., Vanickova. Innovation Corporate Energy Management: Efficiency of Green Investment}

\section{References}

Adamisin, P., Kotulic, R., Mura, L., Kravcakova Vozarova, I. \& Vavrek, R. (2018). Managerial approaches of environmental projects: an empirical study. Polish Journal of Management Studies, 17(1), 27-38. [Google Scholar] [CrossRef]

Agovino, M., Casaccia, M., Crociata, A. \& Sacco, P. L. (2019). European Regional Development Fund and pro environmental behaviour. The case of Italian separate waste collection. Socio-Economic Planning Sciences, 65, 36-50. [Google Scholar] [CrossRef]

Al-Masri, H. M. K., AbuElrub, A., Almehizia, A. A. \& Ehsani, M. (2019). Multi-figure of merit optimisation for global scale sustainable power systems. Renewable Energy, 134, 538-549. [Google Scholar] [CrossRef]

Alons, G. (2017). Environmental policy integration in the EU's common agricultural policy: greening or greenwashing? Journal of European Public Policy, 24 (11), 1604-1622. [Google Scholar] [CrossRef]

Annadanam, S. K., \&Kota, S. H. (2019). Emission of greenhouse gases and criteria pollutants from railways in India estimated using a modified top-down approach. Journal of Cleaner Production, 213, 610-617. [Google Scholar] [CrossRef]

Andersen, F. M., Baldini, M., Hansen, L. G. \& Jensen, C. L. (2017). Households' hourly electricity consumption and peak demand in Denmark. Applied Energy, 208, 607-619. [Google Scholar] [CrossRef]

Arbolino, R., Romano, O. \& De Simone, L. (2017). The role of fiscal incentives for renewable energy on economic growth. International Journal of Business and Society, 18(2), 387-3960. [Google Scholar]

Arbolino, R., Carlucci, F., Cirà, A., loppolo, G. \&Yigitcanlar, T. (2017). Efficiency of the EU regulation on greenhouse gas emissions in Italy: The hierarchical cluster analysis approach. Ecological Indicators, 81, 115-123. [Google Scholar] [CrossRef]

Baltensperger, T., Fuchslin, R. M., Krutli, P. \& Lygeros, J. (2017). European Union gas market development. Energy Economics, 66, 466-479. [Google Scholar] [CrossRef]

Bergman, U. M., Hutchison, M. M. \& Jensen, S. E. H. (2016). Promoting sustainable public finances in the European Union: The role of fiscal rules and government efficiency. European Journal of Political Economy, 44, 1-19. [Google Scholar] [CrossRef]

Burrascano, S., Chytry, M., Kuemmerle, T., Giarrizzo, E., Luyssaert, S., Sabatini, F. M. \& Blasi, C. (2016). Current European policies are unlikely to jointly foster carbon sequestration and protect biodiversity. Biological Conservation, 201, 370-376. [Google Scholar] [CrossRef]

Carley, S., Baldwin, E., MacLean, L. M., \& Brass, J. N. (2017). global expansion of renewable energy generation: an analysis of policy instruments. Environmental and Resource Economics, 68(2), 397-440. [Google Scholar] [CrossRef]

Dyba, W., Loewen, B., Looga, J. \& Zdrazil, P. (2018). regional development in central-eastern european countries at the beginning of the 21st century: Path dependence and effects of EU Cohesion Policy. Quaestiones Geographicae, 37(2), 77-92. [Google Scholar] [CrossRef]

Dziembala, M. (2016). Some considerations on the relationship between economic and social cohesion and implementation of the cohesion policy. Perspectives on Federalism, 8(1), 53-80. [Google Scholar] [CrossRef]

Enshassi, A., Ayash, A. \& Mohamed, S. (2018). Factors driving contractors to implement energy management strategies in construction projects. Journal of Financial Management of Property and Construction, 23(3), 295-311. [Google Scholar] [CrossRef]

Felixova, K. (2012). Evaluation of the absorption intensity of the entrepreneurial support in the regions funded intensely by the government. Economy and Management, 15(1), 17-27. [Google Scholar]

Havlík, V. (2018). Competing discourses of territorial development: tensions between cities and regions as a result of the new regionalism. European Planning Studies, 26(10), 1999-2014. [Google Scholar] [CrossRef]

Humphreys, B. R. (2019). Facility subsidies redux. Journal of Policy Analysis and Management, 38(1), 277-279. [Google Scholar] [CrossRef]

Chabbi, A., Loescher, H. W. \& Dillon, M. S. (2017). Integrating environmental science and the economy: innovative partnerships between the private sector and research infrastructures. Frontiers in Environmental Science, 5, 49. [Google Scholar] [CrossRef]

Indradewa, R., Tjakraatmadja, J. H., \&Dhewanto, W. (2017). Open innovation between energy companies in developed and developing countries: resource-based and knowledge-based perspectives. International Journal of Business Innovation and Research, 12(2), 137-151. [Google Scholar] [CrossRef]

Ishikawa, J., \& Okubo, T. (2017). greenhouse-gas emission controls and firm locations in north-south trade. Environmental and Resource Economics, 67(4), 637-660. [Google Scholar] [CrossRef]

Junker, H., \& Domann, C. (2017). Towards industry 4.0 in corporate energy management. WIT Transactions on Ecology and the Environment, 214, 49-56. [Google Scholar] [CrossRef]

Kisiala, W., Bajerski, A.\& Stepinski, B. (2018). Preferences of poles concerning the shape of regional policy and the allocation of European funds. Transylvanian Review of Administrative Sciences, 14(54), 55-72. [Google Scholar] [CrossRef]

Klímova, V. \& Zitek, V. (2015). Innovation paradox in the Czech Republic: Economic theory and political reality. Political Economy, 63(2), 147-166. [Google Scholar] [CrossRef]

Knoke, B., Missikoff, M. \& Thoben, K. D. (2017). Collaborative open innovation management in virtual manufacturing enterprises. International Journal of Computer Integrated Manufacturing, 30(1), 158-166. [Google Scholar] [CrossRef]

Kostić, M. (2016). Regional sectoral structure of the support realised through the Operational Programme Enterprise and Innovation 2007-2013. Ergo, 11(1), 12-24. [Google Scholar] [CrossRef] 


\section{R., Vanickova. Innovation Corporate Energy Management: Efficiency of Green Investment}

Kulyk V., \& Skodova Parmova, D. (2017). E-business development: the comparative study of the czech republic and the ukraine. Deturope, 9(1), 80-110. [Google Scholar]

Latif, H. H., Gopalakrishnan, B., Nimbarte, A. \& Currie, K. (2017). Sustainability index development for manufacturing industry. Sustainable Energy Technologies and Assessments, 24, 82-95. [Google Scholar] [CrossRef]

Lenkova, O. V., Kot, A. D., Yakunina, O. G. \& Yumsunov, M. S. (2018). Lean manufacturing as a way of employees' motivation in energy saving. International Journal of Engineering and Technology (UAE), 7 (14), 376-380. [CrossRef]

Levanen, J., \& Eloneva, S. (2017). Fighting sustainability challenges on two fronts: Material efficiency and the emerging carbon capture and storage technologies. Environmental Science and Policy, 76, 131-138. [Google Scholar] [CrossRef]

Lim, H., Kim, C., Cho, Y., \& Kim, M. (2017). Energy saving potentials from the application of heat pipes on geothermal heat pump system. Applied Thermal Engineering, 126, 1191-1198. [Google Scholar] [CrossRef]

Liu, P., \& Xie, H. (2013). Research on Small And Medium-Sized Enterprises Promoting Policy. Lecture Notes in Electrical Engineering, 227 (5), 229-235. [Google Scholar] [CrossRef]

Mageshwaran, G., Britto Joseph, G., Sivaji, T., Durairaj Nithiyanantham, R. B., \& Maruthairaja (2018). Energy saving in an air conditioning system using modified HVAC unit as an energy reducer. International Journal of Ambient Energy, 39(7), 719-725. [Google Scholar] [CrossRef]

Mahmood, D., Javaid, N., Ahmed, I., Niaz, I. A.\& Khan, Z. A. (2017). Multi-agent-based sharing power economy for a smart community. International Journal of Energy Research, 41(14), 2074-2090. [Google Scholar] [CrossRef]

Mense, A. (2018). The Value of Energy Efficiency and the Role of Expected Heating Costs. Environmental and resource economics, 71(3), 671-701. [Google Scholar] [CrossRef]

Miller, L., \& Carriveau, R. (2018). A review of energy storage financing - Learning from and partnering with the renewable energy industry. Journal of Energy Storage, 19, 311-319. [Google Scholar] [CrossRef]

Miller, W., \& Senadeera, M. (2017). Social transition from energy consumers to prosumers: Rethinking the purpose and functionality of eco-feedback technologies. Sustainable Cities and Society, 35, 615-625. [Google Scholar] [CrossRef]

Moen, J. (2019). Corporate returns to subsidised R\&D projects: direct grants vs. tax credit financing. International Journal of Technology Management, 79(1), 84-101. [Google Scholar] [CrossRef]

Monasterolo, I., \& Raberto, M. (2019). The impact of phasing out fossil fuel subsidies on the low-carbon transition. Energy Policy, 124, 355-370. [Google Scholar] [CrossRef]

Percoco, M. (2017). Impact of European Cohesion Policy on regional growth: does local economic structure matter? Regional Studies, 51(6), 833-843. [Google Scholar] [CrossRef]

Prashar, A. (2017). Energy efficiency maturity (EEM) assessment framework for energy-intensive SMEs: Proposal and evaluation. Journal of Cleaner Production, 166, 1187-1201. [Google Scholar] [CrossRef]

Radicic, D., \& Pugh, G. (2017). R\&D programmes, policy mix, and the 'european paradox': Evidence from European SMEs. Science and Public Policy, 44(4), 497-512. [Google Scholar] [CrossRef]

Raji, V. P., Srivastava, U., Singh, S. K., Ramesh, L., \& Jain, K. K. (2016). A pilot study on electrical power audit in an institutional office. International Conference on Electrical, Electronics and Optimization Techniques, ICEEOT 2016, 7755189, 2720-2724. [Google Scholar] [CrossRef]

Rogge, N., De Jaeger, S., \& Lavigne, C. (2017). waste performance of nuts 2-regions in the eu: a conditional directional distance benefit-of-the-doubt model. Ecological Economics, 139, 19-32. [Google Scholar] [CrossRef]

Sedlacek, M. (2015). Subsidy Effect On Enterprise Competitiveness - Preliminary Analysis. Politicka Ekonomie, 63(4), 474497. [Google Scholar]

Scheurer, L., \& Haase, A. (2018). Diversity and social cohesion in European cities: Making sense of today's European Unionurban nexus within cohesion policy. European Urban and Regional Studies, 25(3), 337-342. [Google Scholar] [CrossRef]

Sineviciene, L., Sotnyk, I. \& Kubatko, O. (2017). Determinants of energy efficiency and energy consumption of Eastern Europe post-communist economies. Energy and Environment, 28(8), 870-884. [Google Scholar] [CrossRef]

Sobotkova, L. (2015). The evaluation of impacts of usage of subsidies from regional operational programs. Scientific Papers of the University of Pardubice, Series D: Faculty of Economics and Administration, 22(35), 114-127.

Spiller, E., Sopher, P., Martin, N., Mirzatuny, M., \& Zhang, X. (2017). The environmental impacts of green technologies in TX. Energy Economics, 68, 199-214. [Google Scholar] [CrossRef]

Stefaniak, J. (2013). Absorption chillers in solar cooling systems as an example of modern technology for sustainable development. Rocznik Ochrona Srodowiska, 15(1), 1216-1227. [Google Scholar]

Stefanek, R., \& Bockova, K. (2011). How to manage risks in Czech and Slovak engineering projects. Economical and Management, 14(4), 67-77. [Google Scholar]

Tascu, A. V. (2014). Structural instruments 2007-2013 - Regional development guarantee. Quality - Access to Success, 15, 265-270. [Google Scholar]

Trianni, A., Cagno, E., \& De Donatis, A. (2014). A framework to characterise energy efficiency measures. Applied Energy, 118, 207-220. [Google Scholar] [CrossRef]

Trotta, G., Spangenberg, J., \& Lorek, S. (2018). Energy efficiency in the residential sector: identification of promising policy instruments and private initiatives among selected European countries. Energy Efficiency, 11(8), 2111-2135. [Google Scholar] [CrossRef] 


\section{R., Vanickova. Innovation Corporate Energy Management: Efficiency of Green Investment}

Vochozka, M., \& Marouskova, A. (2017). Economic aspects of carbon management in sewage sludge treatment. Energy Sources, Part A: Recovery, Utilisation, and Environmental Effects, 39(5), 485-489. [Google Scholar] [CrossRef]

Waldo, S., \& Paulrud, A. (2017). Reducing greenhouse gas emissions in fisheries: the case of multiple regulatory instruments in Sweden. Environmental and Resource Economics, 68(2), 275-295. [Google Scholar] [CrossRef]

Wilkesmann, M., \& Wilkesmann, U. (2018). Industry 4.0 - organising routines or innovations? VINE Journal of Information and Knowledge Management Systems, 48(2), 238-254. [Google Scholar] [CrossRef]

Wokoun, R., Kolarik, P., \& Kolarikova, J. (2016). Evaluation of entrepreneurs with a focus on operational programme enterprise and innovation (OPEI). Results of a Questionnaire Survey. Economics and Sociology, 9(4), 272-288. [Google Scholar] [CrossRef]

Wolisz, H., Schutz, T., Blanke, T., Wesseling, M., \& Muller, D. (2017). Cost optimal sizing of smart buildings' energy system components considering changing end-consumer electricity markets. Energy, 137, 715-728. [Google Scholar] [CrossRef]

Радка Ванічкова,

Ph.D., доцент, Техніко-економічний інститут в Чеське Будейовице, Чеська республіка

Інноваційний енергоменеджмент компанії: ефективність зелених інвестицій

Метою статті є аналіз еффективності інновацій в енергоменеджменті компаній. Автором проаналізовано дієвість інвестииійних субсидій для енергоефекттивних проєктів компаній за умови наявності та відсутності їх закріплення в Оперативній програми «Підприємство та інновації». Автором систематизовано літературні джерела та підходи до формування та імплементації Оперативної програми «Підприємство та інновації», "Екоенергетика» та інших програм у сфрері енергозбереження. У статті проаналізовано фрактичну та прогнозовану економію енергії, забезпечену інвестиційними субсидіями на енергоефективні проєкти компаній, що функціонують відповідно до принципів екологічної політики Європейського Союзу та з дотриманням правил субсидування у Чеській республіиі. У статті наголошено, що Європейські кліматичні фонди спрямовують свої інвестиції виключно у проєкти, що сприяють підвищенню рівня енергозбереження та покращення якості атмоссрерного повітря. Теоретичним підгрунтям дослідження $є$ науков напрацювання зарубіжних та чеських науковців, що займаються вивченням даної проблематики. Детерміновану вибірку дослідження сфрормовано на основі даних динаміки продаж, рівня енергоефективності, обсягів зелених інвестицій компаній, ефрективності корпоративного управління з 2011 по 2015 роки. У статті проаналізовано ефрективність енергоефективних інвестицій за допомогою компаративного аналізу обсягів залучених інвестииій та кількістю реалізованих енергоесективних заходів. Автором визначено ефективність імплементації програми «Екоенергетика» у порівнянні з аналогічними програми у енергозбереженні. Об'єктом дослідження є компанія, що ффункиіонує у Чеській республіці з 480 працюючими та річним оборотом 520 млн чеських крон. Результати дослідження емпірично підтверджують та теоретично доводять статистично значущий вплив періоду окупності інвестииій, внутрішньої норми їх прибутковості та чистої приведеної вартості (відображає загальну приведену вартість грошових потокіє інвестиційних проєктів), а також наявність інвестиційних субсидій на прийняття рішень інвесторів щодо інвестування у енергоесективні інноваційні проєкти.

Ключові слова: екологічна політика ЄС, структурні фонди, Програма оперативної діяльності «Підприємство та інновації», корпоративна енергоефективність, інвестиційні субсидії, чиста приведена вартість.

Manuscript received: 06.11.19

(C) The author(s) 2020. This article is published with open access at Sumy State University. 